\title{
Comparative Morphological and Anatomical Studies on Morus Species (Moraceae) in Turkey
}

\section{Türkiye'deki Morus Türleri (Moraceae) Üzerinde Karşılaştırmalı Morfolojik ve Anatomik Çalışmalar}

\author{
(D) Zeynep Büşra ERARSLAN*, (D) Sevde KARAGÖZ, (D) Şükran KÜLTÜR \\ İstanbul University Faculty of Pharmacy, Department of Pharmaceutical Botany, İstanbul, Turkey
}

\begin{abstract}
Objectives: Morus alba L., Morus nigra L., and Morus rubra L. are widely cultivated in many countries due to their nutritive, economic, and medicinal value. In this study, comparative morphological and anatomical studies on three common Morus L. species found in Turkey were carried out. According to the results, differences regarding the morphological and anatomical features of these species were described, and the data were displayed in detailed photographs.

Materials and Methods: Specimens collected from different provinces of Turkey were studied. In the anatomical studies, investigations were performed on transversal and superficial sections of the leaves. All sections were stained with chloral hydrate and Sartur solution and were then examined using an Olympus $\mathrm{BH} 2$ light microscope.

Results: Significant diagnostic characteristics were found, such as trichome types, stomatal measurements, the stomatal index, and the density ratio of the parenchyma and collenchyma layers. Some morphological features of the leaves also showed prominent differences.

Conclusion: Our results may contribute to the taxonomy of Morus species for future work and be helpful in species diagnosis.
\end{abstract}

Key words: Moraceae, Morus, anatomy, morphology, Turkey

öz

Amaç: Morus alba L., Morus nigra L. ve Morus rubra L. türleri gıdai, ekonomik ve tıbbi değerleri nedeniyle birçok ülkede yaygın olarak yetiștirilmektedir. Bu çalışmada, Türkiye'de bulunan Morus L. türleri üzerinde karşılaştırmalı morfolojik ve anatomik incelemeler yapılmıştır. Sonuçlara göre, türlerin morfolojik ve anatomik özellikleri ile ilgili farklılıklar tanımlanmış ve elde edilen veriler detaylı fotoğraflarla gösterilmiştir.

Gereç ve Yöntemler: Türkiye'nin farklı illerinden toplanan örnekler çalışılmıştır. Anatomik çalışmalarda, yaprakların enine ve yüzeysel kesitleri üzerinde incelemeler gerçekleștirilmiştir. Tüm kesitler kloralhidrat ve Sartur çözeltisi ile boyanmış ve ardından Olympus BH2 ışık mikroskobu kullanılarak incelenmiştir.

Bulgular: Trikom tipleri, stomatal ölçümleri, stomal indeksi, parenkima ve kollenkima tabakalarının yoğunluk oranları gibi belirgin diagnostik karakterler bulunmuştur. Yaprakların bazı morfolojik özellikleri de belirgin farklılıklar göstermiştir.

Sonuç: Sonuçlarımız, gelecek çalışmalar için Morus türlerinin taksonomisine katkıda bulunabilir ve türlerin ayırt edilmesinde yardımcı olabilir. Anahtar kelimeler: Moraceae, Morus, anatomi, morfoloji, Türkiye 


\section{INTRODUCTION}

The genus Morus L. belongs to the Moraceae (mulberry) family, which contains 37 genera and nearly 1,100 species distributed throughout tropical and temperate regions worldwide. Morus species are generally known as mulberries, and their distribution is extent to East, West, and South East Asia, South Europe, the South of North America, the Northwest of South America, and some parts of Africa. It can be said that they have a high adaptation capacity for various environmental conditions. ${ }^{12}$ Mulberries are under cultivation in many different world regions, such as tropical, subtropical, and temperate zones of Asia, Europe, North and South America, and Africa. These species have economic value in most countries because of their use in sericulture. Moreover, they have been widely used as traditional folk medicine, particularly in China and India. ${ }^{3,4}$

Mulberries are grown for the production of edible fruits in other countries like Turkey and Greece. ${ }^{5}$ They have a long history of cultivation, having been cultivated as food plants for more than 400 years in Turkey, one of the most important centers of diversity. ${ }^{6}$ In Turkey, the best known species are black mulberry (Morus nigra L.), white mulberry (Morus alba L.), and purple mulberry (Morus rubra L.).,7,8 Besides the traditional medicinal use of various part of these species, their fruits are also used in making syrup, jam, pulp, ice-cream, vinegar, and natural dyes. ${ }^{2,6}$ Flavonoids, anthocyanin and alkaloids contained in the most of parts of mulberries ensure several pharmacological activities such as antidiabetic, antioxidant, antiinflammatory, antimutagenic, anticarcinogenic, and hepatoprotective properties. 4,9

According to the APG IV classification system, the family Moraceae belongs to the order Rosales within the Rosids clade. $^{10}$ Diagnostic indicators of Moraceae include the presence of milky latex, a distinct stipule, anatropous ovules, apical placentation, compound fruits (achenes or syconous), and a cystolith." The genus Morus has also attracted the attention of many researchers due to its interesting breeding system, interspecific hybridization, wide distribution range, naturalization in different areas, invasiveness of some taxa, and taxonomic uncertainty within the genus. ${ }^{12}$ Taxonomists have reported various species numbers; thus, the taxonomy of Morus has been unstable. In the first instance, Linnaeus defined seven species belonging to the genus, but then Burea ${ }^{13}$ and Koidzumi ${ }^{14}$ identified 5 and 24 species, respectively. We currently know that Morus comprises about 14 species throughout the world. ${ }^{15}$ Although many taxonomic studies and revisions have been conducted on Morus, taxonomic difficulties related to the genus still remains. ${ }^{7,16,17}$
Morphological and anatomical properties are basic tools that have been used in taxonomic studies for centuries.18,19 Despite certain morphological differences, sometimes fruits of $M$. nigra and M. rubra may not be identified by local people, and sellers replace $M$. nigra with an another less expensive black fruit. ${ }^{20}$ Moreover, some taxa show minor differences in leaf morphology. ${ }^{7}$ Anatomical studies of leaves provide many important diagnostic characteristics, such as the size, shape, and orientation of stomata, guard cells, and subsidiary cells; type and shape of trichomes; and structure of epidermal cells. ${ }^{21}$ For these reasons, determining the morphological and anatomical differences between species could be helpful in resolving diagnostic challenges.

Several studies have been performed on the morphology and anatomy of Morus.,22-26 However, the leaf anatomy and morphology of Morus species from Turkey have not been investigated. The present study aims to investigate the morphological and anatomical features of M. alba, M. nigra, and M. rubra distributed in Turkey. We also attempted to identify diagnostic anatomical and morphological properties that could contribute to the taxonomy of the genus.

\section{Experimental}

Herbarium specimens were used to determine morphological and anatomical properties. M. alba collected from Balıkesir [Herbarium of İstanbul University Faculty of Pharmacy (ISTE) 109772] and İstanbul (ISTE 116445), M. nigra collected from İstanbul (ISTE 80737), and M. rubra collected from Gaziantep (ISTE 40076) are stored in the ISTE. Collected data on each studied species are shown in Table 1. Morphological studies were carried out on herbarium materials. For anatomical studies, leaves were pretreated by immersion in warm water. Minimum 15 individual specimens were used. Hand sections were taken from samples with a razor blade then stained with chloral hydrate and Sartur solution. ${ }^{27}$ Sections were examined using an Olympus $\mathrm{BH} 2$ light microscope, and detailed photos were taken using a Canon Power Shot A640 camera. Measurements of each samples were performed with $\mathrm{KAMERAM}^{\odot}$ software, and the obtained data are given below. The stomatal index (SI) was calculated according to the following formula: SI: (S/S + E) x100, where S refers to the number of stomata per unit area, and $E$ to the number of epidermal cells in the same unit area. ${ }^{28}$ No further statistical analysis was used.

Table 1. Collection data of Morus taxa examined

\begin{tabular}{ll}
\hline Taxon & Locality, voucher number (ISTE) \\
\hline Morus alba & B1 Balıkesir: Kepsut, Büyükkatrancı village, 800 m elevation, 30.05.2015, ISTE 109772 \\
\hline Morus nigra & A2 (E) İstanbul: Çatalca, İnceğiz gateway, field border, 50 m elevation, 25.05.2003, ISTE 80737 \\
\hline Morus rubra & C6 Gaziantep: Between Nizip-Gaziantep, Altındağ village, 650 m elevation, 30.05.1978, ISTE 40076 \\
\hline
\end{tabular}

ISTE: Herbarium of İstanbul University Faculty of Pharmacy 


\section{RESULTS AND DISCUSSION}

The lamina anatomical traits of the collected specimens were defined by examination of the lamina transverse and surficial sections.

\section{Morus alba L.}

The midrib is rich in collenchymatic elements with 4-5 layered collenchyma located under the lower epidermis, 2-3 layered collenchyma are located under the upper epidermis (Figure 1A$G$ ). Between 5 and 6 layers of parenchyma cells exist between the collenchyma layers and the collateral vascular bundles (Figure 1A). The average leaf thickness at the midrib is 735.105 $\mu \mathrm{m}$. Moreover, plenty of druse crystals of calcium oxalate were observed in the midrib and the mesophyll of the leaf (Figure 1C, F, I). Prismatic crystals were observed only in the midrib region. The density of the crystals is increased near the veins in the midrib (Figure 1C).

There is a single layered epidermis covered with a thin cuticle on both adaxial and abaxial surface of the lamina. The epidermis has polygonal cells with usually straight anticlinal
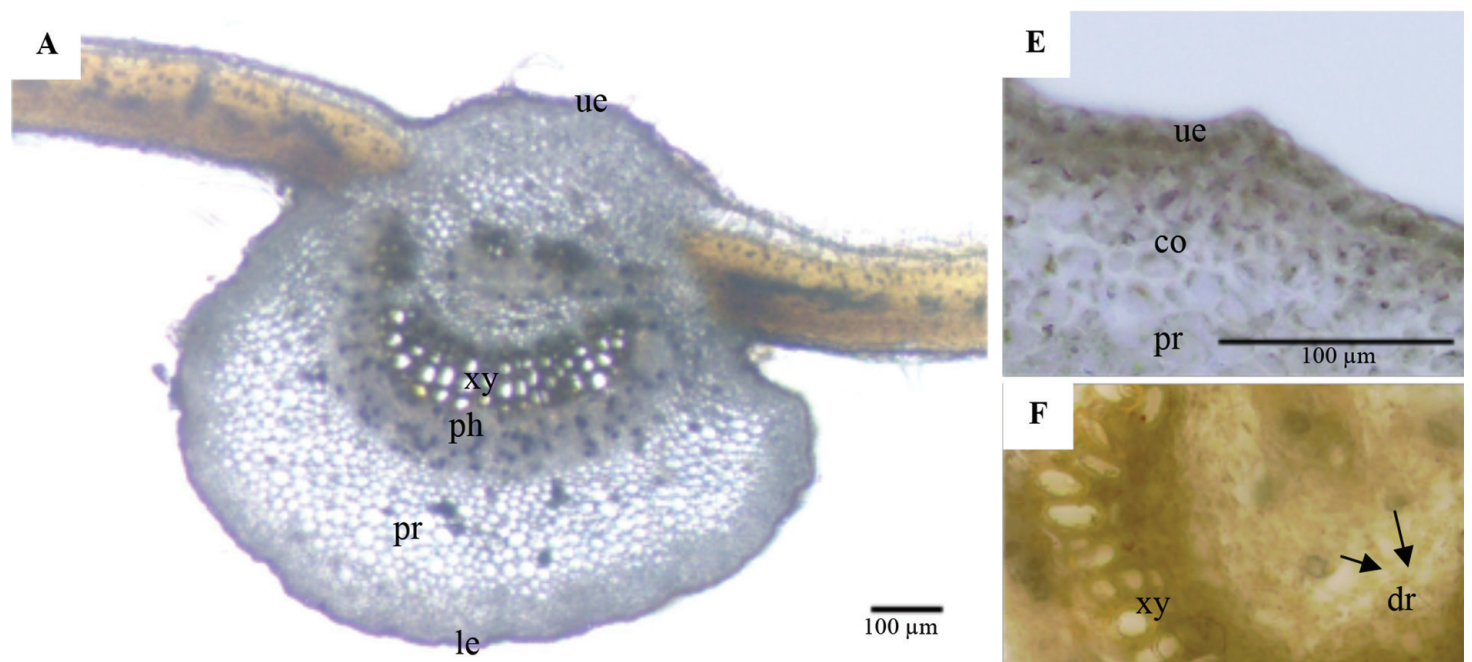

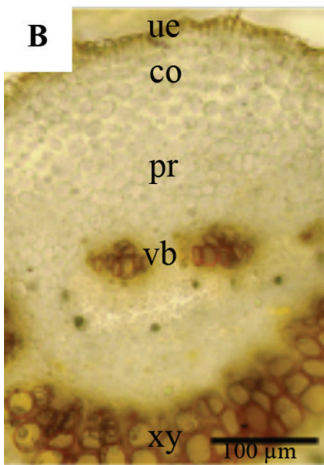

C

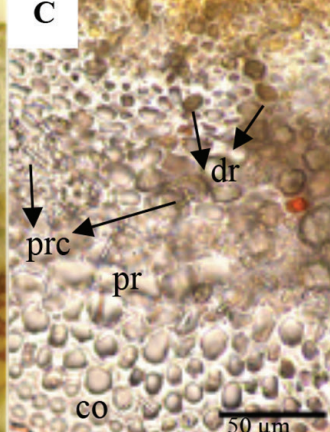

\section{D}

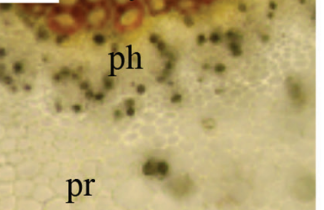

pr
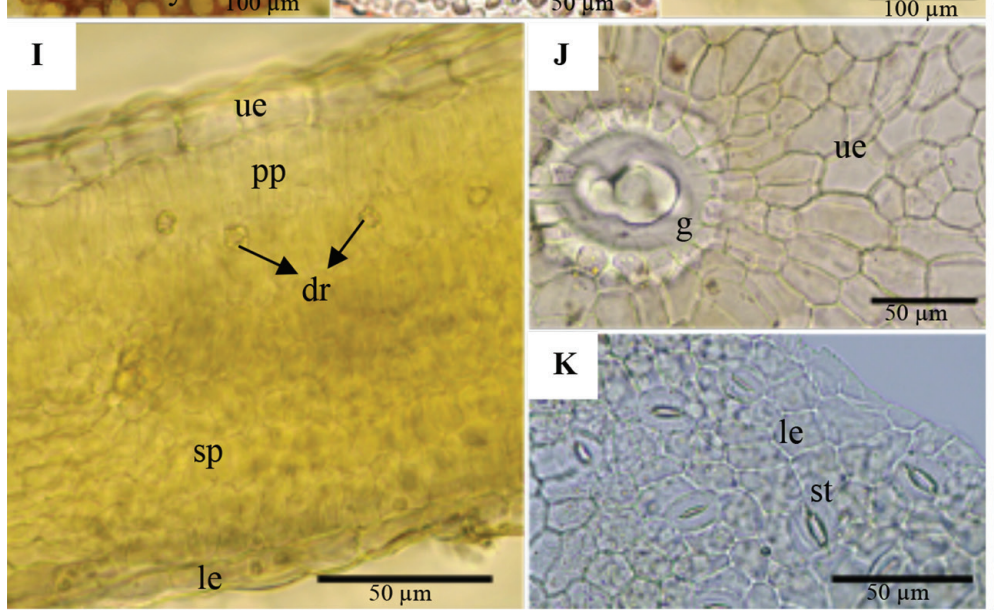
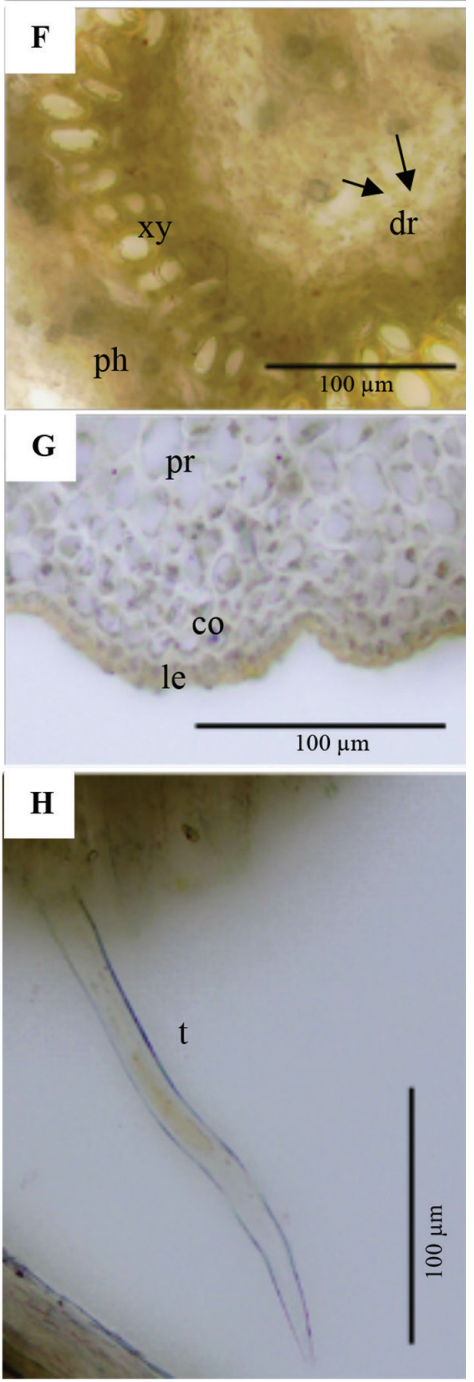

Figure 1. The transverse and surface sections of the leaf of Morus alba. The midrib region (A-H), mesophyll (I), adaxial surface (J), and abaxial surface $(K)$ co: Collenchyma, dr: Druse, g: Peltate gland, le: Lower epidermis, ph: Phloem, pp: Palisade parenchyma, pr: Parenchyma, prc: Prismatic crystal, sp: Spongy parenchyma, st: Stomata, t: Non-glandular trichome, ue: Upper epidermis, xy: Xylem, vb: Vascular bundle 
Table 2. Measurements from leaf anatomical traits of Morus alba, Morus nigra, and Morus rubra (mean, min-max values)

\begin{tabular}{llll} 
& Morus alba & Morus nigra & Morus rubra \\
\cline { 2 - 4 } & Length $\mathrm{x}$ width $(\mu \mathrm{m})$ & Length $\mathrm{x}$ width $(\mu \mathrm{m})$ & Length $\mathrm{x}$ width $(\mu \mathrm{m})$ \\
\hline UEC & $32.93(23.62-44.06) \times 24.41(18.34-33.63)$ & $20.14(15.55-28.67) \times 18.24(15.21-19.87)$ & $38.50(37.81-40.42) \times 20.51(19.15-22.38)$ \\
\hline LEC & $19.73(13.13-29.40) \times 11.43(8.00-12.94)$ & $18.25(16.03-22.41) \times 8.31(8.05-8.64)$ & $28.13(26.95-30.18) \times 13.61(13.05-14.86)$ \\
\hline LS & $18.99(15.39-23.37) \times 14.22(11.81-17.36)$ & $19.12(16.71-21.19) \times 13.97(12.76-15.48)$ & $34.22(31.39-36.98) \times 23.44(19.84-$ \\
$26.33)$ & 45.008 \\
\hline PPL (thickness) & 56.139 & 40.081 & 71.222 \\
\hline SPL (thickness) & 86.254 & 72.685 & \\
\hline
\end{tabular}

UEC: Upper epidermis cell, LEC: Lower epidermis cell, LS: Stomata of abaxial epidermis, PPL: Palisade parenchyma layer, SPL: Spongy parenchyma layer, min: Minimum, max: Maximum

walls, and the upper epidermis cells are larger than the lower ones. The length and width of epidermis cells are presented in Table 2. Unicellular non-glandular trichomes, varying in length, are also present on the both leaf surfaces. The number of nonglandular trichomes is higher along the veins and the midrib (Figure 1A, H). Glandular trichomes with a unicellular stalk and multicellular head are sparse on the lower surface. The leaf is dorsiventral. The mesophyll is composed of two layers of palisade cells under the upper epidermis and 5-6 layers of spongy cells under the lower epidermis. Cylindrical palisade cells were found in the transverse section. Spongy parenchyma cells with wide intercellular spaces have ovoid or circular shapes (Figure 1I). The spongy parenchyma occupies about $60.57 \%$ of the mesophyll. Stomata cells were found only on the abaxial surface of the leaf (hypostomatic) (Figure 1J, K). The leaf blade thickness ranges from 159.096 to $175.017 \mu \mathrm{m}$, with a mean value of $169.112 \mu \mathrm{m}$.

On the abaxial surface, anomocytic stomata are oval shaped and vary in size. They are situated at the same level as the other epidermal cells (mesomorphic). Each stoma is surrounded by $5-6$ subsidiary cells (Figure $1 \mathrm{~K}$ ). Lithocysts, a specific type of enlarged epidermal cells in which calcium carbonate is deposited, and peltate glands were detected on the upper surface of the leaf (Figure 1J). The SI for the lower surface of the lamina was calculated as 10.71 .

\section{Morus nigra $L$.}

Regarding the midrib region, 2-3 layered collenchyma are presented on the lower surface and 1-2 layered collenchyma on the upper surface (Figure 2A-F). Between 5 and 6 layers of parenchyma cells fill the space between the collenchyma layers and the collateral vascular bundles (Figure 2A, B). The leaf thickness at the midrib is on average $516.083 \mu \mathrm{m}$. Many druse crystals of calcium oxalate were observed in the midrib and the mesophyll (Figure 2B, C, E, I, J). Several prismatic crystals were observed only in the midrib region. The crystals are abundant near the veins in the midrib (Figure 2B, C).

Both leaf surfaces have a single layered epidermis covered with a thin cuticle. Epidermis cells, which are polygonal in shape, usually have straight anticlinal walls. Their sizes are variable. The upper epidermal cells are larger than the lower ones (Table 2). Unicellular, non-glandular trichomes were observed on both leaf surfaces, and their number was higher on the lower surface (Figure 2A, D, G). Glandular trichomes with a unicellular stalk and multicellular head are scattered on both surfaces (Figure $2 \mathrm{H}$ ). The mesophyll consists of two layers of palisade cells under the upper epidermis and 4-5 layers of spongy cells with wide intercellular spaces under the lower epidermis. Hence, the leaf is dorsiventral. While the palisade parenchyma cells were cylindrical, the spongy parenchyma cells were found to be ovoid-circular in transverse section (Figure $2 \mathrm{l}, \mathrm{J}$ ). The spongy parenchyma occupies approximately $64.46 \%$ of the mesophyll. The leaf is also hypostomatic and mesomorphic, stomata cells were found only on the lower surface of the leaf (Figure 2K-M). Leaf blade thickness ranges from 149.042 to $160.843 \mu \mathrm{m}$, with a mean value of $158.052 \mu \mathrm{m}$.

The stomata are anomocytic. They have an oval shape and vary in size. Each stoma is surrounded by 5-6 subsidiary cells (Figure 2L). Lithocysts and peltate glands were defined on the upper surface of the leaf (Figure 2I, K). The SI for the lower surface of the lamina was calculated as 13.26.

\section{Morus rubra L.}

In the midrib, while 2-3 layered collenchyma are located under the lower epidermis, 1-2 layered collenchyma are located under the upper epidermis (Figure 3A-G). Parenchyma cells form 4-5 layers. They are present between the collenchyma layers and the collateral vascular bundles. The leaf thickness at the midrib is on average $740.899 \mu \mathrm{m}$. Many druse crystals of calcium oxalate were observed in the midrib and also in the mesophyll (Figure 3B, C, F). Several prismatic crystals were observed only in the midrib region.

The epidermis cells, which are covered by a thin cuticula layer on both surfaces of the leaf, is single layered. Their shape is polygonal, and they vary in size (Table 2). However, the upper epidermis cells are larger than the lower epidermis cells. They usually have straight anticlinal walls. On both leaf surfaces, indumentum of unicellular non-glandular trichomes were noticed, but they were more numerous on the lower surface (Figure $3 \mathrm{H}, \mathrm{I}$ ). Glandular trichomes with a unicellular stalk and head were rare on both surfaces. The leaf is dorsiventral and 
hypostomatic (Figures 3J-L). The mesophyll is differentiated into palisade and spongy parenchyma. It comprises one layer of palisade cells under the upper epidermis and 3-4 layers of spongy cells with wide intercellular spaces under the lower epidermis. Palisade parenchyma cells are cylindrical, and the spongy parenchyma cells are ovoid-circular (Figure 3J). The spongy parenchyma occupies about $61.28 \%$ of the mesophyll. Leaf blade thickness ranges from 125.705 to $133.690 \mu \mathrm{m}$, with a mean value of $130.398 \mu \mathrm{m}$.
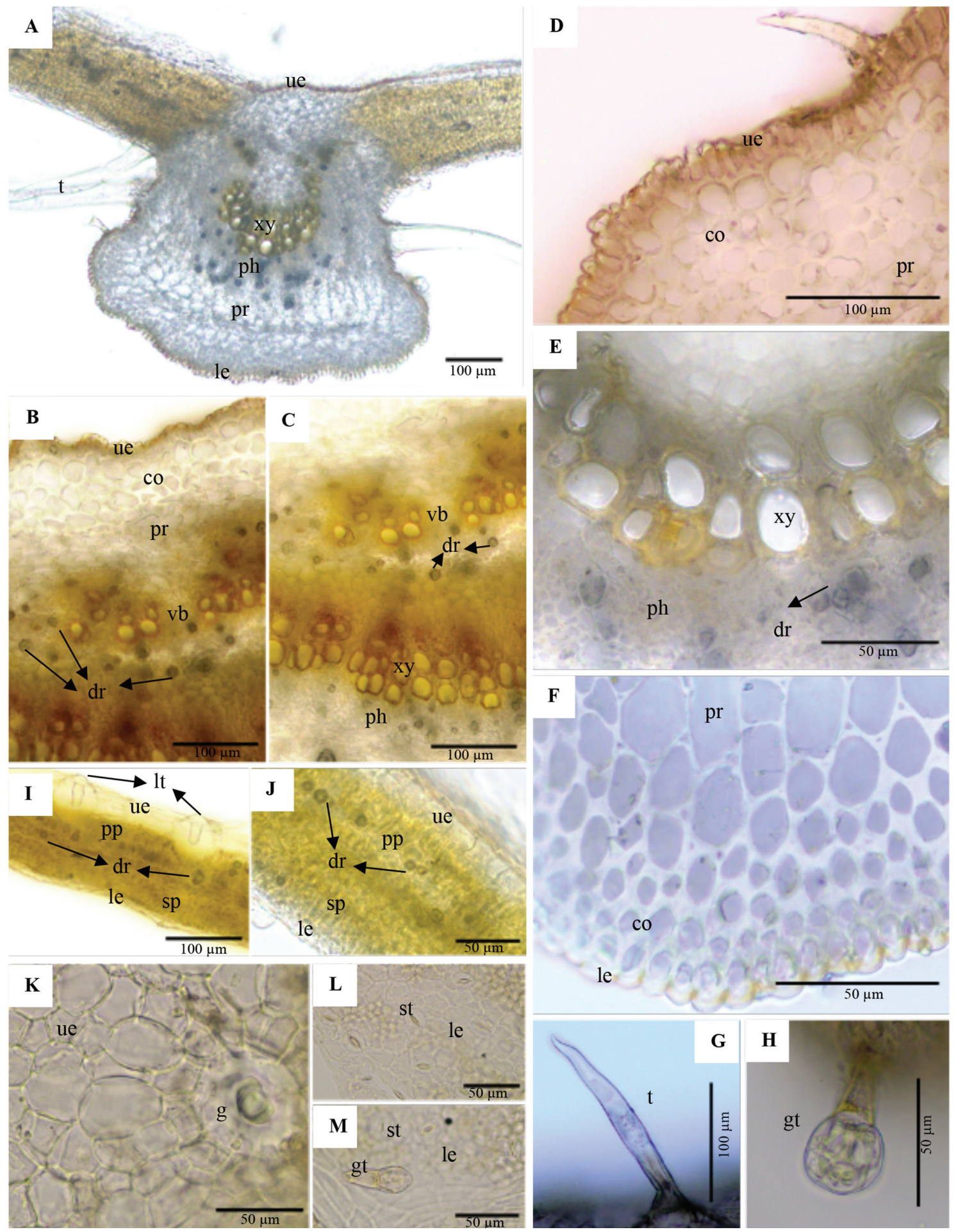

Figure 2. The transverse and surface sections of the leaf of Morus nigra. The midrib region (A-H), mesophyll (I), ( J), adaxial surface (K), and abaxial surface $(\mathrm{L}, \mathrm{M})$

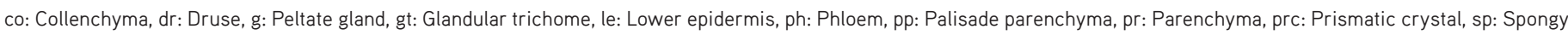
parenchyma, st: Stomata, t: Non-glandular trichome, ue: Upper epidermis, xy: Xylem, vb: Vascular bundle 
Oval shaped and different sized stomata are anomocytic. Each stoma is surrounded by 5-6 subsidiary cells, and the leaf is mesomorphic (Figure $3 \mathrm{~L}$ ). Lithocysts and peltate glands were found on the upper surface of the leaf (Figure 3K). The SI for the lower surface of the lamina was calculated as 11.11 .
Morus species could vary in morphological appearance when the climate or habitat change. Hence, it is difficult to assign a taxonomic classification to these species. ${ }^{23}$ Comparative morphological and anatomical studies are the basic tools of plant taxonomy, and they provide fundamental data which are helpful for a majority of classification systems. ${ }^{29}$ Furthermore,
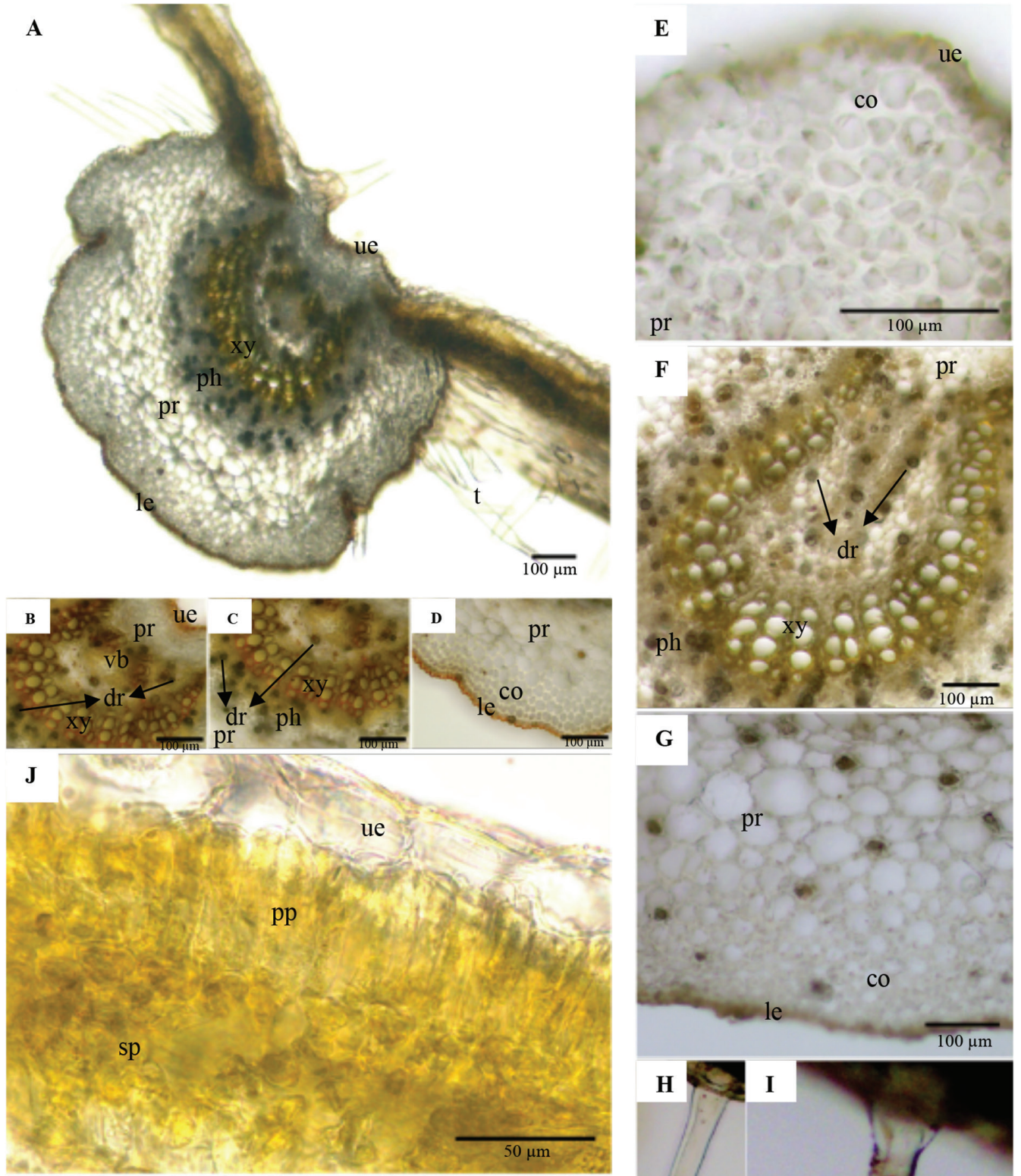
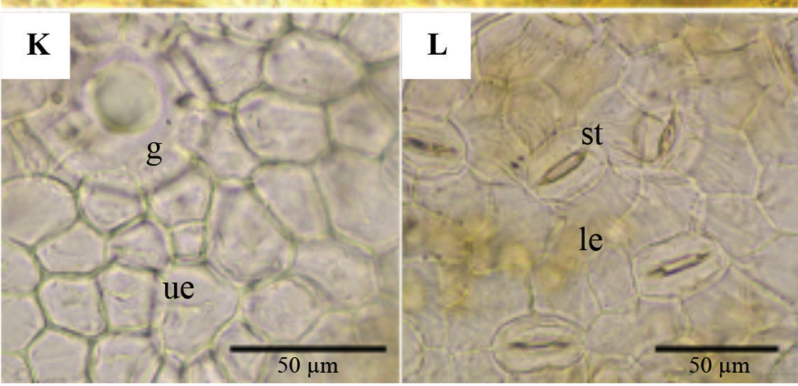

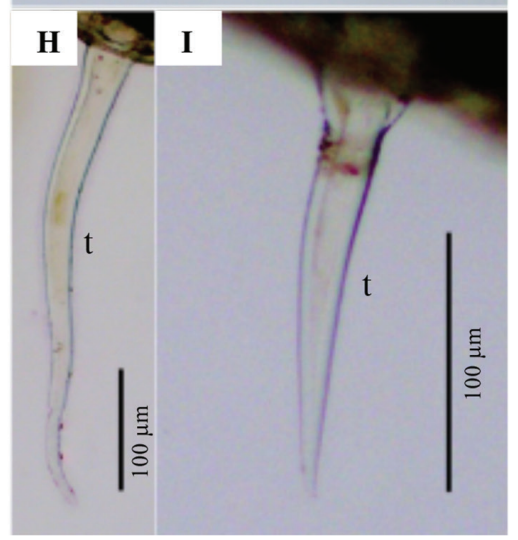

Figure 3. The transverse and surface sections of the leaf of Morus rubra. The midrib region (A-l), mesophyll (J), adaxial surface (K), and abaxial surface ( $\mathrm{L}$ ) co: Collenchyma, dr: Druse, g: Peltate gland, le: Lower epidermis, ph: Phloem, pp: Palisade parenchyma, pr: Parenchyma, prc: Prismatic crystal, sp: Spongy parenchyma, st: Stomata, t: Non-glandular trichome, ue: Upper epidermis, xy: Xylem, vb: Vascular bundle 
studies based on plant morphology and anatomy help us to understand the phylogeny of life..$^{30}$ In this study, M. alba, M. nigra, and $M$. rubra were examined and compared morphologically and anatomically. Differences as a result of the investigation are given in Table 3.

Certain morphological characteristics, such as leaf shape, size, base, margin, and indumentum were found to be useful for identifying the studied species (Figure 4). Moreover, the indumentum of the shoot and the peduncle and the size of the fruit, peduncle, and petiole differ in these species. The species with the broadest leaves was found to be M. alba. The difference in the color of the fruits of these three species is perhaps the most striking organoleptic feature. M. alba has white, pinkish, or purplish fruit, whereas M. nigra has blackish-violet or black fruit, and M. rubra has dark reddish-purple fruit. Moreover, there are some similarities in their morphological features, such as inflorecences of short, dense spikes, ellipsoid syncarps, and fleshy drupelets.

We also know that some anatomical traits are very diagnostic. Thus, they are frequently used in routine identification. Since the leaf is regarded as the most varied organ of the angiosperms, taxonomic studies of various taxa were carried out on the basis of leaf anatomy. ${ }^{29,31-34}$ These studies present many anatomical characteristics of potential taxonomic significance. ${ }^{29}$ The

Table 3. Morphological and anatomical comparison of the studied taxa

\begin{tabular}{|c|c|c|c|}
\hline & Morus alba & Morus nigra & Morus rubra \\
\hline Shoots & Slender, glabrous & Stout, pubescent & Slender, pubescent \\
\hline Peduncle & Hairy & Hairy & Pubescent \\
\hline Peduncle length & (1-) $2 \mathrm{~cm}$, circa as long as syncarp & $1-1.5 \mathrm{~cm}$ & $0.5-1 \mathrm{~cm}, 1 / 2$ as long as syncarp \\
\hline Fruit length & (1-) $1.5-2.5 \mathrm{~cm}$ & $(1.5-) 2-2.5 \mathrm{~cm}$ & $(1.5-) 2-3 \mathrm{~cm}$ \\
\hline Fruit color & White, pinkish, or purplish & Blackish-violet or black & Dark reddish-purple \\
\hline Leaf shape & Ovate to broadly ovate & Broadly ovate & Broadly ovate to oblong-ovate \\
\hline Leaf size & $3-10(-18) \times 2-12 \mathrm{~cm}$ & $5-12(-20) \times(4)-5.5-13 \mathrm{~cm}$ & $6-12(-20) \times 4-10 \mathrm{~cm}$ \\
\hline Leaf apex & Acute or shortly acuminate & Acute or shortly acuminate & Abruptly long-acuminate \\
\hline Leaf base & Rounded or obliquely cordate & Deeply cordate & Truncate or subcordate \\
\hline Leaf margin & Crenate-dentate & Serrate & Serrate \\
\hline Indumentum of leaf & $\begin{array}{l}\text { Upper surface glabrous/lower surface } \\
\text { pubescent on the midrib and the veins }\end{array}$ & $\begin{array}{l}\text { Upper surface scabrous/lower } \\
\text { surface pubescent }\end{array}$ & $\begin{array}{l}\text { Upper surface slightly scabrous/lower } \\
\text { surface roughly hairy }\end{array}$ \\
\hline Non-glandular trichomes & $\begin{array}{l}\text { Unicellular trichomes on the both leaf } \\
\text { surfaces (density is higher along the } \\
\text { veins and the midrib) }\end{array}$ & $\begin{array}{l}\text { Unicellular trichomes on the } \\
\text { both leaf surfaces (density is } \\
\text { higher on the lower surface) }\end{array}$ & $\begin{array}{l}\text { Unicellular trichomes on the both leaf } \\
\text { surfaces (density is higher on the } \\
\text { lower surface) }\end{array}$ \\
\hline Glandular trichomes & $\begin{array}{l}\text { Trichomes with unicellular stalk and } \\
\text { multicellular head on the lower surface } \\
\text { (sparsely) }\end{array}$ & $\begin{array}{l}\text { Trichomes with unicellular stalk } \\
\text { and multicellular head on the } \\
\text { both surface }\end{array}$ & $\begin{array}{l}\text { Trichomes with unicellular stalk and } \\
\text { head on the both surfaces (rarely) }\end{array}$ \\
\hline Epidermal cells & $\begin{array}{l}\text { Upper epidermis cells are larger than } \\
\text { the lower ones }\end{array}$ & $\begin{array}{l}\text { Upper epidermis cells are larger } \\
\text { than the lower ones }\end{array}$ & $\begin{array}{l}\text { Upper epidermis cells are larger than } \\
\text { the lower ones }\end{array}$ \\
\hline Mesophyll type & Dorsiventral & Dorsiventral & Dorsiventral \\
\hline Mesophyll & $\begin{array}{l}38 \%-45 \% \text { palisade parenchyma ( } 2 \\
\text { layer) }\end{array}$ & $\begin{array}{l}35 \%-38 \% \text { palisade } \\
\text { parenchyma ( } 2 \text { layer) }\end{array}$ & $\begin{array}{l}35 \%-40 \% \text { palisade } \\
\text { parenchyma (one layer) }\end{array}$ \\
\hline Location of stomata & Hypostomatic & Hypostomatic & Hypostomatic \\
\hline Stomatal index & 10.71 & 13.26 & 11.11 \\
\hline $\begin{array}{l}\text { Collenchyma } \\
\text { cell layers of midrib }\end{array}$ & $\begin{array}{l}\text { 4-5 layered on the lower surface, } 2-3 \\
\text { layered on the upper surface }\end{array}$ & $\begin{array}{l}2-3 \text { layered on the lower } \\
\text { surface, } 1-2 \text { layered on the } \\
\text { upper surface }\end{array}$ & $\begin{array}{l}\text { 2-3 layered on the lower surface, } 1-2 \\
\text { layered on the upper surface }\end{array}$ \\
\hline $\begin{array}{l}\text { Thickness of leaf blade } \\
\text { (average) }\end{array}$ & $169.112 \mu \mathrm{m}$ & $158.052 \mu \mathrm{m}$ & $130.398 \mu \mathrm{m}$ \\
\hline $\begin{array}{l}\text { Thickness of midrib } \\
\text { (average) }\end{array}$ & $735.105 \mu \mathrm{m}$ & $516.083 \mu \mathrm{m}$ & $740.899 \mu \mathrm{m}$ \\
\hline Petiole length & $1-3.5(-4) \mathrm{cm}$ & $1.5-3.5 \mathrm{~cm}$ & (1-) $1.5-3 \mathrm{~cm}$ \\
\hline
\end{tabular}



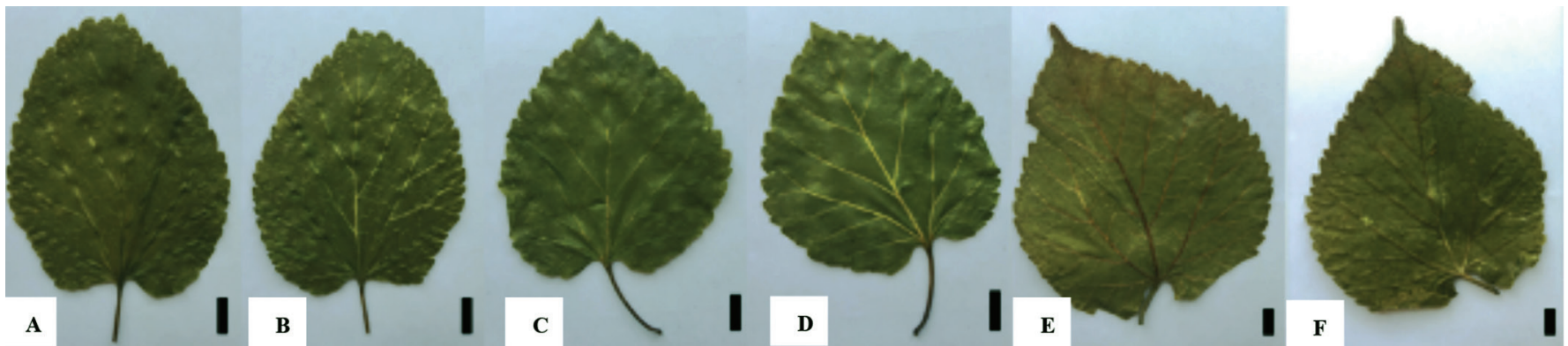

Figure 4. General view of the leaves of Morus species. Upper surface of the leaf of Morus alba (A), lower surface of the leaf of M. alba (B), upper surface of the leaf of Morus nigra (C), lower surface of the leaf of M. nigra (D), upper surface of the leaf of Morus rubra (E), lower surface of the leaf of M. rubra (F), bar: $1 \mathrm{~cm}$

results of our detailed anatomical study revealed that there were some differences among the leaf anatomy of these three taxa. Metcalfe and Chalk ${ }^{35}$ have reported that the epidermis of the Moraceae generally comprises of a single layer of quadrangular or elongated anticlinal cells. Although the upper epidermis cells were found to be larger than the lower ones in all studied taxa, the length and width of epidermis cells on the two sides differed. Accordingly, the epidermis cells on the lower and upper surfaces of M. nigra were found to be smaller than those in the other two taxa. Since the stomatal size may change according to environmental conditions, some authors do not regard this as a diagnostic characteristic. However, the stomatal size is generally accepted because the size of the stomata is generally stable enough to be used as a diagnostic characteristic. ${ }^{36,37}$ In the Moraceae family, stomata usually do not have special subsidiary cells. ${ }^{38,39}$ Leaves of the three taxa were determined to be hypostomatic (stomata were only observed on the abaxial surface) with anomocytic-type stomata. However, concerning size, the width, and length of stomata were significantly different. The mean value of the stomata size of $M$. rubra was found to be the highest species. The term SI is used to define stomatal frequency, and the size of the epidermal cells is neglected. Since taxa from distinct localities have more or less constant SI values, the SI is considered as a significant taxonomic characteristic. ${ }^{36,40}$ In the taxa studied, different values of the SI were calculated in this study.

Many studies have revealed the taxonomic value of trichomes in angiosperms. ${ }^{41,42}$ Glandular and non-glandular trichomes are common in the Moraceae. ${ }^{18,22,38}$ According to a previous study, while simple, unicellular, non-glandular trichomes and multicellular, capitate, glandular trichomes are common in Morus taxa, conical unicellular non-glandular trichomes and bicellular capitate glandular trichomes are rare. ${ }^{38}$ Abbasi et al. ${ }^{26}$ indicated that unicellular non-glandular and glandular trichomes and also hooked hairs are present on the leaf surfaces of Morus species. Moreover, multicellular glandular trichomes, unicellular non-glandular trichomes and cystolith trichomes were observed in $M$. alba and $M$. nigra. ${ }^{22}$ In the present study, unicellular non-glandular trichomes of various sizes were found on both leaf surfaces of the studied taxa, but their densities were variable. Glandular trichomes with a unicellular stalk and multicellular head were detected in $M$. alba, M. nigra, and glandular trichomes with a unicellular stalk and head were observed in M. rubra. We also found peltate glands on the upper surfaces of all studied taxa, as in previous studies. ${ }^{24,26,43}$

In the Moraceae family, calcium oxalate and carbonate crystals are mostly present in the leaves. $18,25,33,44,45$ Regarding calcium oxalate, two types of crystals (druse crystals in the cells of the mesophyll and bundle sheaths, prismatic crystals only in the cells of the bundle sheath) are located in the leaves of the Moraceae. ${ }^{44}$ The most often seen calcium carbonate crystal type cystolith (a calcified body) are located in several families, such as Urticaceae, Ulmaceae, Moraceae, Cucurbitaceae, and Acanthaceae.118,46 Many species of the Moraceae are recognized by the presence of cystolith. Cystolith is deposited in a specialized cell called a lithocyst, which is known as an excretory idioblast ${ }^{18,44,46-48}$ Lithocysts are very common in the Moraceae family and were observed in many anatomical studies on Moraceae. Ficus L. species mostly have lithocysts; moreover, they were reported on Morus leaves. ${ }^{33,37,44,45}$ According to Esau ${ }^{49}$ the presence and location of crystals may be distinctive and useful in taxonomic classification. In our study, while many druse crystals were found in the mesophyll and also in the midrib region, prismatic crystals were only found in the midrib. Furthermore, lithocysts were noticed only on the upper surface of the leaves of all investigated taxa. In contrast to our study, lithocysts were not observed in some studies on Morus taxa. $22,24,26$

As seen in transverse sections, spongy and palisade parenchyma cells can be distinguished easily from each other in the mesophyll. However, palisade parenchyma layers and their ratio of occupation vary. The leaves of the studied taxa are dorsiventral. The dorsiventral leaf is characteristic of some members of the Moraceae family and is therefore not useful for species identification. ${ }^{18,35}$ Besides, in some works on the Moraceae family, dorsiventral and isobilateral leaves were reported. ${ }^{33,37,50-52}$ In this study, collateral vascular bundles were seen in the midrib region. The differences were determined concerning collenchymatic elements located with various layers between epidermal and parenchyma cells on the midrib of the three taxa. 


\section{CONCLUSION}

Some differences were determined in the morphological and anatomical properties of all studied taxa. It is obvious that certain characteristics, such as the size, shape, and indumentum of leaves, are helpful in the recognition of taxa. Furthermore, some anatomical characteristics of the leaves were found to be of diagnostic importance, such as the ratio of the density of the palisade parenchyma and collenchyma layers in the midrib region, type, and density of trichomes, length and width of stomata, and SI. All of these characteristics are environmentally influenced, and future studies analyzing plants from several localities are needed; nevertheless, they can be very useful in the delimitation of species.

Conflicts of interest: No conflict of interest was declared by the authors. The authors alone are responsible for the content and writing of the paper.

\section{REFERENCES}

1. Clement WL, Weiblen GD. Morphological evolution in the Mulberry family (Moraceae). Syst Bot. 2009;34:530-552.

2. Ercişli S, Orhan E. Chemical composition of white (Morus alba), red (Morus rubra) and black (Morus nigra) mulberry fruits. J Food Chem. 2007;103:1380-1384.

3. Özgen M, Serçe S, Kaya C. Phytochemical and antioxidant properties of anthocyanin-rich Morus nigra and Morus rubra fruits. Sci Hortic. 2009;119:275-279.

4. Ramesh HL, Sivaram V, Yogananda Murthy VN. Antioxidant and medicinal properties of mulberry (Morus sp.): A review. World J Pharm Res. 2014:3:320-343.

5. Zafar MS, Muhammad F, Javed I, Akhtar M, Khaliq T, Aslam B, Waheed A, Yasmin R, Zafar H. White mulberry (Morus alba): a brief phytochemical and pharmacological evaluations account. Int J Agric Biol. 2013;15:612-620.

6. Eyduran SP, Ercişli S, Akın M, Beyhan Ö, Geçer MK, Eyduran E, Ertürk YE. Organic acids, sugars, vitamin C, antioxidant capacity, and phenolic compounds in fruits of white (Morus alba L.) and black (Morus nigra L.) mulberry genotypes. J Appl Bot Food Qual. 2015;88:134-138.

7. Browicz K. Morus L. (Moraceae). In: Davis PH, ed. Flora of Turkey and the East Aegean Islands (Vol 7). Edinburgh: Edinburgh Univ Press;1982:641-642.

8. Karlıoğlu, N. Morus L. In: Akkemik Ü, ed. Türkiye'nin Doğal-Egzotik Ağaç ve Çalıları., Ankara: Orman Genel Müdürlüğü Yayınları; 2018:423-424.

9. Deniz GY, Laloğlu E, Koç K, Nadaroğlu H, Geyikoğlu F. The effect of black mulberry (Morus nigra) extract on carbon tetrachloride-induced liver damage. Arch Biol Sci. 2018;70:371-378.

10. APG IV. An update of the Angiosperm Phylogeny Group classification for the orders and families of flowering plants: APG IV. Bot J Linn Soc. 2016;181:1-20.

11. Pramanick DD. A synoptic account of the family Moraceae in Uttarakhand. eJAFE. 2017;5:17-26.

12. Burgess KS, Morgan M, Husband BC. Interspecific seed discounting and the fertility cost of hybridization in an endangered species. New Phytol. 2008;177:276-284.
13. Burea, E. Moraceae. In: DeCandolle A, ed. Prodromus Systematis Naturalis Regni Vegetabilis (Vol. 17). Paris: Treuttel et Würtz;1873:211-288.

14. Koidzumi G. Taxonomy and phytogeography of the genus Morus. Bull Seric Exp Stn. 1917;3:1-62.

15. Zeng Q, Chen H, Zhang C, Han M, Li T, Qi X, Xiang Z, He N. Definition of eight mulberry species in the genus Morus by internal transcribed spacer-based phylogeny. PLoS One. 2015;10:e0135411.

16. Rao CK, Jarvis CE. Lectotypification, taxonomy and nomenclature of Morus alba, M. tatarica and M. indica (Moraceae). Taxon. 1986;35:705-708.

17. Zhou Z, Gilbert MG. Moraceae. In: Wu Z, Raven PH, Hong D, eds. Flora of China (Vol. 5). Beijing: Science Press; 2003:21-73.

18. Solereder H. Systematic Anatomy of the Dicotyledons: A Handbook for Laboratories of Pure and Applied Botany (Vol 1). Oxford; Clarendon Press: 1908.

19. Radford AE, Dikison WC, Massey JR, Bell CR. Vascular Plants Systematics (1 ${ }^{\text {st }}$ ed). New York: Harper \& Row; 1974.

20. Erdoğan Ü, Pırlak L. Utilization and production of mulberry (Morus spp.) in Turkey. Alatarım. 2005;4:38-43.

21. Dickison WC. Integrative plant anatomy. $1^{\text {st }}$ ed. San Diego: Academic Press; 2000.

22. Azizian D. Morphology and distribution of trichomes in some genera (Morus, Ficus, Broussonetia and Maclura) of Moraceae. Iran J Bot. 2002;9:195-202.

23. Biasiolo M, Da Canal MT, Tornadore N. Micromorphological characterization of ten Mulberry cultivars (Morus spp). Econ Bot. 2004;58:639-646.

24. Munir M, Khan MA, Ahmed M, Bano A, Ahmed SN, Tariq K, Tabassum S, Mukhtar T, Ambreen M, Bashir S. Foliar epidermal anatomy of some ethnobotanically important species of wild edible fruits of northern Pakistan. J Med Plants Res. 2011;5:5873-5880.

25. Kumar V, Kodandaramaiah J, Rajan MV. Leaf and anatomical traits in relation to physiological characteristics in mulberry (Morus sp.) cultivars. Turk J Bot. 2012;36:683-689.

26. Abbasi AM, Mir AK, Mushtaq A, Mamoona M, Muhammad Z, Shazai S, Mishwani ZR, Zahid U. Ethnobotanical and taxonomic screening of genus Morus for wild edible fruits used by the inhabitants of Lesser Himalayas-Pakistan. J Med Plant Res. 2014;8:889-898.

27. Çelebioğlu S, Baytop T. A new reagent for microscopial investigation of plant. İstanbul: Publication of the Institute of Pharmacognosy; 1949.

28. Salisbury EJ. On the cause and ecological significance of stomatal frequency with special reference to the woodland flora. Philos Trans R Soc Lond B Biol Sci. 1927;216:1-65.

29. Taia WK. Modern trends in plant taxonomy. Asian J Plant Sci. 2005;4:184-206

30. Scotland RW, Olmstead RG, Bennett JR. Phylogeny reconstruction: The role of morphology. Syst Biol. 2003;52:539-548.

31. Baranova M. Systematic anatomy of the leaf epidermis in the Magnoliaceae and some related families. Taxon. 1972;21:447-469.

32. Stace CA. The Taxonomic Importance of Leaf Surface. In: Heywood VH, Moore DM, eds. Current Concepts in Plant Taxonomy. London: Academic Press;1984:67-94.

33. Van Greuning JV, Robbertse PJ, Grobbelaar N. The taxonomic value of leaf anatomy in the genus Ficus. S Afr J Bot. 1984;3:297-305. 
34. Klimko M, Truchan M. Morphological variability of the leaf epidermis in selected taxa of the genus Ficus L. (Moraceae) and its taxonomic implications. Acta Soc Bot Pol. 2006;75:309-324.

35. Metcalfe CR, Chalk L. Anatomy of the Dicotyledons: Leaves, Stem, and Wood in Relation to Taxonomy with Notes on Economic Uses (Vol 2). Oxford: Clarendon Press; 1950.

36. Wilkinson HP. The Plant Surface (Mainly Leaf). In: Metcalfe CR, Chalk L, eds. Anatomy of the Dicotyledons (Vol 1). Oxford: Clarendon Press;1979:97-117.

37. Chantarasuwan B, Baas P, Heuven BJ, Baider C, Welzen PC. Leaf anatomy of Ficus subsection Urostigma (Moraceae). Bot J Linn Soc. 2014;:175:259-281.

38. Gangadhara M, Inamdar JA. Trichomes and stomata, and their taxonomic significance in the Urticales. Plant Syst Evol. 1977;127:121-137.

39. Letz R, Uhríková A, Májovský J. Chromosome numbers of several interesting taxa of the flora of Slovakia. Biologia (Bratisl). 1999;54:4349.

40. Ajayan KV, Babu RL, Patil Bayakka B. Variability of stomatal index and chlorophyll content in four species of Solanaceae members. Int Res J Biological Sci. 2015;4:16-20.

41. Theobald WL, Krahulik JL, Rollins RC. Trichome Description and Classification. In: Metcalfe CR, Chalk L, eds. Anatomy of the Dicotyledons (Vol 1). Oxford: Clarendon Press; 1979:40-53.

42. Batterman MRW, Lammers TG. Branched foliar trichomes of Lobeliodeae (Campanulaceae) and the infrageneric classification of Centropogon. Syst Bot. 2004;29:448-458.
43. Ogunkunle ATJ. The value of leaf epidermal characters in diagnosing some Nigerian species of Ficus L. (Moraceae). Res J Bot. 2013;8:1-14.

44. Wu C, Kuo-Huang L. Calcium crystals in the leaves of some species of Moraceae. Bot Bull Acad Sinica. 1997;38:97-104.

45. Nur Fatihah HN, Nashriyah M, Nor Zaimah AR, Khairil M, Ali AM. Leaf morphology and anatomy of 7 varieties of Ficus deltoidea (Moraceae). Turk J Botany. 2014;38:677-685.

46. Setoguchi $H$, Okazaki M, Suga S. Calcification in higher plants with special reference to cystoliths. In: Crick RE, ed. Origin, evolution, and modern aspects of biomineralization in plants and animals. New York: Plenum Press; 1989:409-418.

47. Foster AS. Plant idioblasts: remarkable examples of cell specialization. Protoplasma. 1956;46:184-193.

48. Cutler DF, Botha T, Stevenson DW. Plant anatomy: An applied approach. $1^{\text {st }}$ ed. Malden: Blackwell Publishing; 2008.

49. Esau K. Plant anatomy. $2^{\text {nd }}$ ed. New York: Wiley; 1965.

50. Dixon DJ. A comparison of the leaf anatomy of Ficus subpuberula, F. atricha and F. brachypoda (Moraceae: Urostigma section Malvanthera). Nuytsia. 2002;15:27-32.

51. Sonibare MA, Jayeola AA. Egunyomi A. Comparative leaf anatomy of Ficus Linn. species (Moraceae) from Nigeria. J Appl Sci. 2006;6:30163025.

52. Araújo ND, Coelho VPM, Ventrella MC, Agra MF. Leaf anatomy and histochemistry of three species of Ficus sect. Americanae supported by light and electron microscopy. Microsc Microanal. 2013;20:296-304. 